\section{Biofuels might create more emissions than they save}

The use of biofuels could sharply increase greenhouse-gas emissions by driving the conversion of native land to agriculture, according to research published online last week in Science.

Timothy Searchinger from Princeton University in New Jersey and his colleagues suggest that it takes 167 years for the emissions reductions gained by burning corn ethanol to make up for the sharp spike in emissions caused by clearing new land for farms (T. Searchinger et al. Science doi:10.1126/science.115861;2008).

And a second study, led by Joseph Fargione of the Nature Conservancy in Minneapolis, Minnesota, calculates that the time needed to clear this 'carbon debt' would vary from 17 to 420 years, depending on the circumstances (J. Fargione et al. Science doi:10.1126/science.1152747; 2008).

But biofuels made from waste biomass, or perennial crops grown on abandoned agricultural lands, offer "immediate and sustained greenhouse-gas advantages”, according to Fargione's team.

\section{Collectors claim trade treaty is obstructive}

The 1973 Convention on International Trade in Endangered Species of Wild Fauna and Flora (CITES) restricts trade in endangered organisms, and the word among scientific collectors is that it restricts their research as well. A paper now illustrates this 'CITES effect' in hard numbers (D. L. Roberts and A. R. Solow Proc. $R$. Soc. B doi:10.1098/rspb.2007.1683; 2008).

David Roberts of the Royal Botanic Gardens in Kew, UK, and Andrew Solow of the Woods Hole Oceanographic Institution in Massachusetts, compared the rate at which two botanical gardens in the United States collected two kinds of plant: orchids, many of which are covered by CITES, and bromeliads, of which very few are. They found that before the convention was ratified, the institutions were collecting three orchids for every bromeliad, but after this time the ratio fell to just $1: 1$.

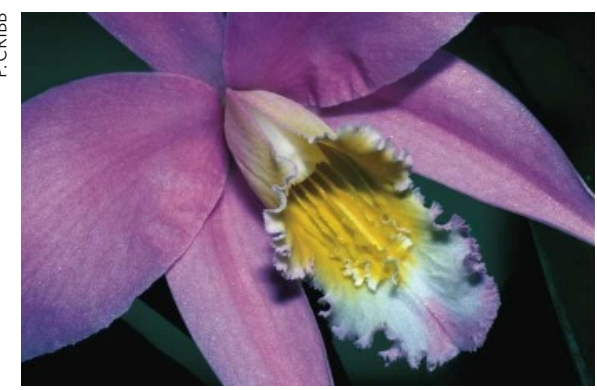

Botanical gardens are shying away from orchids.

\title{
Europe's lab finally arrives at the space station
}

The Columbus research module, Europe's largest contribution to the International Space Station, has finally arrived at its destination.

On 11 February, astronauts Rex Walheim and Stan Love conducted a spacewalk to connect the module to the station (clockwise from top left: Columbus is lifted from the

shuttle, manoeuvred into position and docked onto the space station). Astronauts will now begin preparing the $€ 700$-million (US\$1-billion) lab for experiments in biology, fluid science and physiology. A second spacewalk scheduled for 15 February
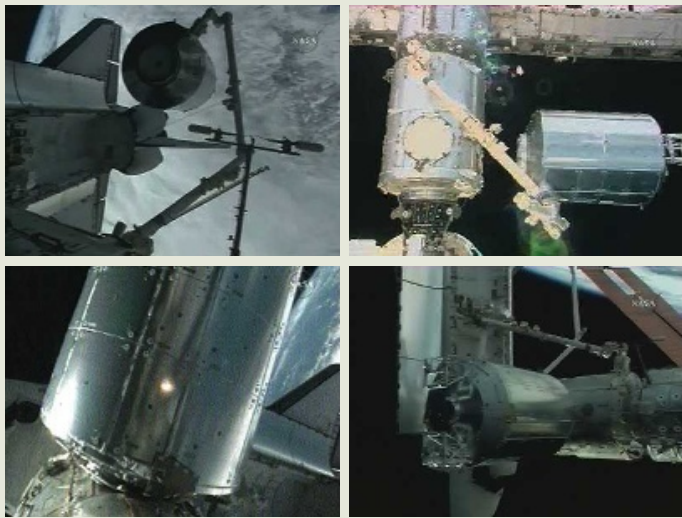

will attach a materials-testing experiment and a solar observatory to the outside of the lab. But many larger experiments will be delayed until 2009, when the station's crew is set to increase to six (see Nature 450, 766-767; 2008). The arrival marks the end of years of delays for Columbus, which was originally set to launch around 2000 .

\section{Illumina unveils genome sequence of African male}

Illumina, a biotechnology company based in San Diego, California, announced on 6 February that it has sequenced the complete genome of an African man.

Scientists have already sequenced the genomes of two Caucasian men and one Chinese man, but Illumina's is the first African genome. It came from an anonymous Yoruban man from Nigeria.

Comparing the data from these four genomes might theoretically yield insights into human diversity. But data from only two of them have been publicly released - those of the scientists James Watson and Craig Venter - and only Venter's genome has been described in a formal publication.

The Illumina announcement came two days before company scientists unveiled their data at the Advances in Genome Biology and Technology conference in Marco Island, Florida.

\section{Head of US environmental health agency resigns}

The head of the National Institute of Environmental Health Sciences in Research Triangle Park, North Carolina, has resigned. David Schwartz stepped aside temporarily last August when an investigation was opened into his management, in part because Congress had questioned him over potential favouritism and having conflicts of interest (see Nature 448, 979; 2007).

"Our community has not universally embraced the scientific direction or strategies that I have implemented," Schwartz wrote in an e-mail to staff. "In my enthusiasm to bring new science and opportunities to our field, it appears that I have inadvertently disenfranchised segments of our community. I sincerely apologize for the pain this may have caused."

Schwartz will now run the pulmonary and critical-care unit at the National Jewish Medical and Research Center in Denver, Colorado; he will also help to create a centre for genetics and therapeutics there.

\section{Cash crisis puts Sunshine Project in the shade}

After eight years, the Sunshine Project, an influential US biosecurity-monitoring group based in Austin, Texas, has suspended its operations.

The project's director, Edward Hammond, says he made the decision because of a chronic cash shortage. "At some point you come to realize that if you don't have buy-in from the people whose business it is to fund peace and security non-governmental organizations, then you have to recognize reality," he says.

Hammond built a reputation for being well-informed as he exposed numerous lapses in biosafety at US universities and research institutes while the country's investment in research on dangerous pathogens ballooned. He was a strong critic of what he alleged were lax controls on rules governing research on pathogens.

\section{READER SURVEY}

Nature Publishing Group is conducting a reader survey to learn about how readers use scientific journals. The answers we receive will enable us to continue to develop the services that you value. As a thank you for your participation, you will be able to enter a prize draw to win an $80 G B$ iPod. To take the survey, please visit www.nature. com and follow the link at the top of the page. 